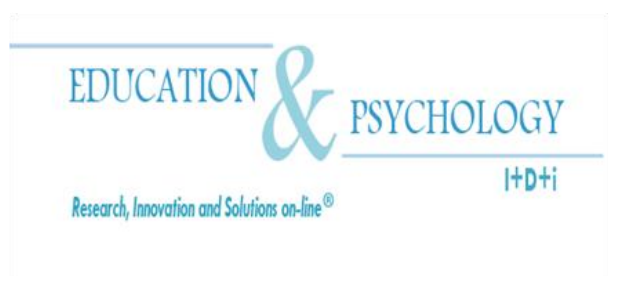

\title{
Preschool age children, divorce and adjustment: a case study in Greek kindergarten
}

\section{Thomas Babalis ${ }^{1}$, Yiota Xanthakou ${ }^{2}$, Christina Papa $^{3}$, Olympia Tsolou $^{4}$}

${ }^{1}$ Assistant Professor, National \& Kapodistrian University, Athens

${ }^{2}$ Associate Professor, University of the Aegean, Rhodes

${ }^{3}$ M.Ed. in Educational Management, University of the Aegean, Rhodes

${ }^{4}$ M.Ed. in Applied Linguistics, M.Sc. in Educational Technology and Management, National \& Kapodistrian University, Athens

\section{Greece}

Correspondence: Thomas Babalis. Department of Primary Education, National \& Kapodistrian University, 20, Ippokratous st., Athens, Greece. E-mail: tbabalis@ primedu.uoa.gr.

C Education \& Psychology I+D+i and Editorial EOS (Spain) 


\section{Abstract}

Introduction. The aim of this research, which was carried out in 2010, is the comparative study of the psychosocial adjustment of preschool children from divorced and nuclear families in the nursery school.

Method. The sample of the study consisted of 60 students (mean age $=5.21$ ), 30 preschool children of divorced parents and 30 preschool children from nuclear families that are enrolled in public kindergartens. The Preschool teachers of the students were interviewed and answered questions with regard to children's school adaptation. Moreover, children drew an imaginary family in the frame of test of family.

Results. The results showed that both groups do not differ as to the general school adjustment, social skills and school performance, but there were significant correlations between the quality of interpersonal relationships and school performance, and the form of the family and the emergence of emotional and / or behavior problems. Finally, the analysis of children's drawings showed significant differentiations between the two groups of the sample at hand.

Discussion. The results of the present study confirm the value of children's drawing and especially of the family test as a diagnostic and evaluative tool of the power of the interfamilial relations and representations that the child has shaped about his/her family. The contemporary kindergarten, which primarily aims at children's cognitive, social and emotional development, can support these children, who, at such tender age, face difficult situations in life. Constant work and effort are required to improve the work of preschool teachers, the upgrading of preschool educational programs and the provision of help to as many children as possible, regardless of conditions and circumstances. Kindergarten and primary school could offer 'abilities rather than disabilities' to children of all social classes and family background, as we should not forget that children's adaptation and success in school are closely related to their social and emotional wellbeing.

Keywords: Single-parent family ${ }^{1}$, parental divorce, nuclear family ${ }^{2}$, preschool age, adjustment, school performance, children's drawing.

\section{Received: 07/09/11 Initial acceptance: 08/10/11 Final acceptance: 11/05/11}

\footnotetext{
${ }^{1}$ In this study, as single-parent family is referred only the one, which emerges after the separation/divorce of parents, where the single parent lives with his/her child/ren. That is, widowship or single motherhood is not under scrutiny.

${ }^{2}$ In this study, as nuclear family is referred the one in which the child lives with both parents.
} 


\section{Niños de edad preescolar, el divorcio y la adaptación: un estudio de caso en la Enseñanza Infantil de Grecia \\ Resumen}

Introducción. El objetivo de esta investigación, realizada en 2010, es el estudio comparativo del ajuste psicosocial de los niños en edad preescolar de familias divorciadas y nucleares, en la guardería.

Método. La muestra del estudio consistió de 60 estudiantes (edad media = 5,21), 30 niños en edad preescolar de padres divorciados y 30 niños en edad preescolar de familias nucleares que están matriculados en guarderías públicas. Los maestros preescolar de los alumnos fueron entrevistados y respondieron a las preguntas con respecto a la adaptación escolar de los niños. Por otra parte, los niños dibujaron una familia imaginaria en el marco de la Prueba de la Familia.

Resultados. Los resultados demostraron que ambos grupos no difieren en cuanto a la adaptación escolar, las habilidades sociales y el rendimiento escolar en general, sino que aparecieron correlaciones significativas entre la calidad de las relaciones interpersonales y el rendimiento escolar, y la forma de la familia y la aparición de problemas emocionales y / o problemas de comportamiento. En último lugar, el análisis de los dibujos de los niños a mano, mostraron diferenciación significativa entre de los dos grupos de la muestra.

Discusión. Los resultados del presente estudio confirman el valor de dibujo para niños y en especial de la prueba de la familia como una herramienta de diagnóstico y de evaluación de la potencia de las relaciones intrafamiliares y las representaciones que el niño ha formado sobre su familia. La guardería contemporánea, que apunta al desarrollo cognitivo, social y emocional de los niños, debe apoyar a estos niños, que, en esta edad tierna, se enfrentan a situaciones difíciles en la vida. Se requieren el trabajo constante y el esfuerzo para mejorar el trabajo de los maestros de preescolar, el desarollo de programas educativos preescolares y la prestación de ayuda a tantos niños como sea posible, independientemente de las condiciones y circunstancias. El jardín de la infancia y la escuela primaria podrían ofrecer "capacidades más bien que inhabilidades" para los niños de todas las clases sociales y contexto familiar, ya que no podemos olvidar que la adaptación de los niños y el éxito en la escuela están estrechamente relacionadas con su bienestar social y emocional.

Palabras Clave: Familia monoparental ${ }^{3}$, divorcio de los padres, familia nuclear ${ }^{4}$, edad preescolar, ajuste, rendimiento escolar, dibujo para niños.

\footnotetext{
${ }^{1}$ En este estudio, como familia monoparental se refiere sólo a una, que surge después de la separación / divorcio de los padres, donde vive el padre o la madre soltero/a con su hijo / s /. Es decir, el widowship o la maternidad individual no se han examinado.

${ }^{2}$ En este estudio, como la familia nuclear se refiere la en la que el niño vive con ambos padres.
} 


\section{Introduction}

In all modern societies, the increase in the number of single-parent families is an undeniable reality, taking into serious consideration the important demographic differentiations that have taken place in recent decades as far as the family structure is concerned. An unavoidable consequence of such a development is an increase in student population that lives in a different form of family organization, which deviates from the conventional nuclear one. The single-parent family is a new form of family, which emerges from the choice of refusing (or losing) the marital relationship, but not the parental one. In the Report of the European Communities (1989), the single-parent family is defined as the family in which one parent without a spouse or partner, but maybe with other people (eg. parents), lives with at least one unmarried child, which depends on him/her.

According to figures of the Greek Statistical Authority (2009) for the year 2001, single-parent families represent a percentage of 8.7 of all households in Greece and of 17.1 for families with children. Nowadays, the passage to the state of being a single parent is mainly through a break-up of the couple (either a marriage or a cohabitation is involved) and to some extent through out-of-wedlock motherhood or widowhood. The increase in the divorce rate has been attributed to the fact that Greek women have now become financially independent and that their educational level has remarkably risen, not to mention the changes in gender roles, the gradual change in attitudes towards divorce and the corresponding legislative changes that have facilitated the legal process of getting a divorce (Hatzichristou, 1999; Kogkidou, 1995).

Parents' separation is a particularly significant and traumatic experience for children. Studies indicate that younger children experience more problems and are more vulnerable to separation (Hetherington, 1989; Kalter \& Rembar, 1981). The high proportion of time that children spend at home along with their reduced ability to understand the changes in their family structure indicate that the changes occurring at an early stage in the child's life may be more painful (Ermisch, Francesconi \& Pevalin, 2004; Mclanahan \& Sandefur, 1994). The most common children's reactions to divorce and changes in their behavior are the following: limited interpersonal skills and aggressive behavior, feelings of guilt as they consider themselves to be responsible for the breakage in their parents' marriage, anger towards their parents 
due to separation, wish for their parents' rejoining, a feeling of insecurity and fear of abandonment by one or both parents (Herbert, 2008; Wallerstein \& Kelly, 1980).

According to contemporary scientific findings, preschool age is of pivotal importance as to the child's development as a whole. The role of kindergarten is important in promoting literacy and school success for all children, as school failure is associated with failure of literacy at younger ages (Clay, 2001). Furthermore, not only does kindergarten aim at providing children with knowledge and skills but helping in their social and emotional adaptation at school as well. Family impact on school adjustment is very important. Family has a defining effect on the student's relationship with the school system, thus influencing his/her whole school life (academic performance, social-emotional development, value system, etc.) (Koutrouba, Antonopoulou, \& Babalis, 2010). The need for effective communication and essential cooperation between school and family for the child's balanced development is widely recognized (Cagliari \& Giudici, 2002; Dodge \& Colker, 1998; Epstein, 1995).

According to the relevant literature, problems regarding various areas of adjustment and school performance are observed in children from single-parent families and especially children of divorced parents in comparison to children from nuclear families (Amato \& Keith, 1991; Cox \& Cox, 1985; Hetherington, Pong, Dronkers \& Hampden-Thompson, 2002). More specifically, school adjustment is considered to be a multidimensional concept defined as the successful coping with difficulties/obstacles, which leads to the satisfaction of the child's basic desires and needs and allows him/her to meet the requirements of the school environment (Miller, Yahne \& Rhodes, 1990; Rathus, Nevid, \& Piggrem, 1986).

The difficulties in school adjustment are of a twofold nature, since there are not only 'learning difficulties' but also emotional and behavioral difficulties. Thus, if the causes of the difficulties of children's adaptation are to be identified, three models of causes should be taken into consideration: the medical, the social and the ecosystemic ones. The latter are closer to reality, as the preschool child is separated from his/her mother for the first time and for a few hours is with strangers in the environment of the kindergarten. This is an experience of immense significancy, and if the child is properly prepared beforehand, he/she is bound not to face any problem in his/her adjustment. If, however, there has been no adequate preparation in the supportive context of his/her family, then the child will most probably be facing an adjustment problem, which must be dealt by the teacher (Bronfenbrenner, 1975, 2005). 
Moreover, it is claimed that the child is well adapted to the preschool level of education, when he/she is able to successfully cope with the problems arising in the new environment, to satisfy his/her needs and be happy, to become part of his/her peer group and to cooperate effectively as a responsible, equal and creative member, cultivating thus his/her mental abilities and developing friendly relations with other children.

In this vein, serving the purposes of the current study, school adjustment is presently examined in the light of three dimensions, that is, sociability, emotional status and school performance, in an attempt to better clarify the concept at hand.

It is worth mentioning that according to the findings of various studies and the metaanalyses of research data carried out in the U.S.A (Amato, 2000) and the other OECD countries (Chapple, 2009; OECD, 2009) regarding the impact of single parenthood on children's adaptation and well-being, it is revealed that the effect of being raised in a single-parent family is of no relevant significance, leaving thus no space for drawing generalized and powerful conclusions. Consequently, single parenthood itself could not be regarded as aggravating and automatically leading to school problems and problematic behavior (Babalis, 2005; Pliogkou, 2008).

The interaction of some critical factors such as the child's temperament, age and gender, the time experienced in single parenthood, the family's socio-economic status, the quality of parent-child relationship, the quality of communication between parents, the involvement of the absent parent in the family, the parents' potential conflict before and after the divorce, the child's relationship with the absent parent and finally the availability of support networks, all play an important role in the child's smooth psycho-emotional development (Cherlin, Furstenberg, Chase-Landsdale, Kierman, Robins, Morrison, \& Teitler, 1991; Hetherington, Bridges \& Insabella, 1998; Hodges, Buchsbaym \& Tierney, 1983).

As far as Greek reality is concerned, there has been a lack of relevant research studies regarding single-parent-family children's adaptation in comparison to those living with both parents. Research has been carried out concerning school age children (Babalis, 2005; Hatzichristou, 1998) and adolescents (Kardasi, 2005), while Riga's and Gkiziaki's research (1994) refers to preschool children. 


\section{Aims of the research}

The aim of the present research is the comparative study of the adjustment of preschool age children from divorced/separated families and their classmates from intact families, within the context of the Greek educational system and in particular, of the kindergarten.

To be more specific, the main objectives were the following: a) the study of pupils' sociability and school performance, according to whether they come from single-parent or nuclear families, as assessed by kindergarten teachers, b) the study of the types and the frequency of emotional-behavioral problems in children of separated/divorced parents, c) the study of the relation of both the divorced parents' communication and the absent parent's relationship with the child to school performance and d) the study of the images that both children of divorced parents and those living with both parents have shaped regarding their family form.

Having, therefore, taken into account the specific parameters of Greek reality, the results of the present study are compared to those of relevant research in other countries and a discussion on their significance is held.

\section{Method}

\section{Participants}

Sixty (60) students (30 pre-school children of separated/divorced parents and 30 preschool children who live with both parents) along with their twenty (21) teachers in the kindergarten participated in the current survey. More specifically, the participants were twentyeight $(28,46.7 \%)$ boys and thirty-two $(32,53.3 \%)$ girls, who attended 21 public kindergartens in the Greek island of Rhodes in 2010. The children's age ranged from four (4) to six (6) years old $(M=5.21, S D=0.48)$. 


\section{Instruments - Procedure}

The data collection was carried out following a two-fold procedure, that is, via an interview and a test, which are described in detail as follows:

\section{Interview}

For the purposes of the data collection and the achievement of the aim and objectives of the research, a structured interview was used. The questions were formulated based on both the theoretical framework of this study, which includes theoretical approaches and results of research studies, and the discussions that were carried out followed by a useful exchange of views with the participants in the research (Gall, Borg, \& Gall, 1996). The effect of single parenthood on children's school adjustment as assessed by their teachers is explored through the dimensions of child's sociability, the occurrence of emotional-behavioral problems and school performance. In addition, through interviews with kindergarten teachers, the quality of both the communication between divorced parents and the absent parent's relationship with the child are under scrutiny.

\section{Test 'Drawing of an imaginary family' of L. Corman}

Children's drawing used as a projective technique for investigating interfamilial relationships comprises a psychological approach, which L. Corman's 'drawing an imaginary family' is based on. The Corman (1990) family drawing test is a projective assessment instrument of immense interpretative value, which reveals elements of the child's personality, the child's emotional state, his/her sense of security and extent of adjustment, the rate of interfamilial relationships and the role the child plays in his/her family environment, as well as his/her emotional disorders, oedipal conflicts, the sibling competition, the value attribution to or the depreciation of parenting patterns and his/her relationships with the wider environment (Bellas, 2000; Corman, 1990; Xanthakou, 2007). More specifically, during early childhood, children's drawing is regarded as the most appropriate psycho-diagnostic assessment instrument in the detection of a child's emotions and personality (Bellas, 2000; Geldard \& Geldard, 2004; Malchiodi, 2001).

According to his/her initial order, the researcher asks the child to draw a fictional family: 'Imagine a family and draw a picture of it'. As stated (Corman, 1990), after gaining the 
trust of the child, the researcher may pose a series of questions on his/her drawing (Xanthakou, 2007). The interview is structured as follows:

1. Your drawing is very nice. So, this is the family that you imagined. Would you like to talk about it? Who are they? Where are they? What are they doing? Tell me about all people, starting with the first person you drew.

2. Now, could you tell me who the best person is in this family? Why?

3. Well, can you tell me now who the least good person is? Why?

4. Will you tell me now who the happiest is? Why?

5. Who is the least happy? Why?

6. You told me that this is a family as you imagined it. Let's say that if you were a member of this family, who you might want to be? Why?

The interview is supplementary to the analysis and interpretation of data. Furthermore, the order of designing human figures and objects, the composition of the child's real family along with his/her reactions, hesitations, scribbles and erasings are recorded. The application of the test 'drawing an imaginary family' is followed by the analysis and interpretation process. The study focuses on the following axons: a) Index of preferences-identifications, b) The level of the content: At this stage, the child's actual family is compared to the imaginary family that he drew, c) The morphological level. At first, the overall drawing is assessed as far as its composition, organization and context are concerned. Following this approach, there is an attempt to contrast the two extreme types of drawing expression: i) the sensory type, which is characterized by his/her sensitivity towards the environment, the movement, the joint action, the warmth of bonds and ii) the rational type, who avoids giving his personal version of the representation of reality, prefers orderly and still forms, puts emphasis on precision, symmetry and logical relations. In the current research, the factor of colour was also assessed. Colours comprise the most expressive element of children's drawing, due to the immense expressive power and emotional load they bear (Bellas, 2000).

\section{Data analysis}

For the purpose of the statistical analysis of the data, the Statistical Package for Social Sciences for Windows (Version 13.0) was used. In particular, the following statistical techniques were applied: 
1. Descriptive statistics, such as mean $(M)$, standard deviation (SD), percentage frequency $(\% f)$ and cumulative percentage frequency.

2. Cross-tabulation statistics [frequency distributions, Pearson chi-square $\left(\chi^{2}\right)$ statistics, Fisher's exact test, Monte Carlo tests, degrees of freedom $(d f)$, significance level] (Argesti, 1990; Siegel \& Castellan, 1988).

The analysis of the interview data was performed with the method of content analysis. The research findings were given to three qualified psychologists to act as external assessors and perform the analysis and interpretation of results, so that the validity and reliability of the Corman family test findings are checked. Therefore, the validity and reliability of the results of the test 'drawing an imaginary family' were ensured.

\section{Results}

Analysis and interpretation of results on interviews of kindergarten teachers

The results showed that there were significant correlations among communication, the relationship between the absent parent and child, and school performance. The results of cross-tabulation analysis between the communication and the relationship child statistically significant correlations (Pearson Chi-square $\chi^{2}=14.400$, df 4, $p<.001$ ). pecifically, among parents with positive, tension and conflict free communication, it was shown that their child developed a good relationship with the absent parent, on the contrary, among parents who had a negative relationship, none of the absent parents had a good relationship with their child, according to kindergarten teachers' opinions.

According to the kindergarten teachers', when the absent parents had a good relationship with their child, then the child showed high school performance, thus indicating that it is important for the child to have a positive, frequent and emotional relationship with the parent, so that the child has a high school performance accordingly (Table 1). 
Table 1. Cross-tabulation of the child's relationship with the absent parent and school performance: Number, percentage frequency and control of statistical significance

Child's relationship with the absent parent

\begin{tabular}{|c|c|c|c|c|c|c|}
\hline \multirow[b]{2}{*}{ School performance } & \multicolumn{2}{|c|}{ Good } & \multicolumn{2}{|c|}{$\mathrm{Bad}$} & \multicolumn{2}{|c|}{ Total } \\
\hline & $f$ & $\% f$ & $f$ & $\% f$ & $f$ & $\% f$ \\
\hline Low & 2 & $16.7 \%$ & 3 & $25 . \%$ & 5 & $20.8 \%$ \\
\hline Moderate & 0 & $0.0 \%$ & 4 & $33.3 \%$ & 4 & $16.7 \%$ \\
\hline High & 10 & $83.3 \%$ & 5 & $41.7 \%$ & 15 & $62.7 \%$ \\
\hline Total & 12 & $100.0 \%$ & 12 & $100.0 \%$ & 24 & $100.0 \%$ \\
\hline
\end{tabular}

Pearson Chi-square $\chi^{2}=5.867, d f 2, p<.05$

Furthermore, the results of cross-tabulation between the form of family and children's sociability did not support the existence of statistically significant (Pearson Chi-square $\chi^{2}=$ $.403, d f 2, n s)$ among children from divorced families and children from nuclear families, according to the kindergarten teachers' views. Finally, cross-tabulation between the form of family (nuclear and single parent) and children's academic performance were not statistically significant (Pearson Chi-square $\chi^{2}=3.388, d f 2, n s$ ). However, despite the fact that no statistically significant differences emerged between the two family types, it seems that children who lived with both parents showed higher school performance compared to those of singleparent families.

An important issue which was raised during the interviews with the nursery school teachers is the emotional and behavioral problems of preschool age children. In particular, of the total number of students, sixteen children (16, or percentage $53.3 \%)$ had emotional and behavioral problems, based on the kindergarten teachers' assessments, while that was not the case with the other fourteen children (14, or percentage $46.7 \%$ ). Particularly, of the total number of sixteen (16) students, ten of them (10, or percentage $62.6 \%)$ were classified as quite energetic, one (1, or percentage $6.3 \%)$ as aggressive, five $(5$, or percentage $31.5 \%)$ did not participate in class, four (4, or percentage $25.2 \%$ ) showed concentration problems, three (3, or percentage $18.9 \%$ ) had speech difficulties, and finally two (2, or percentage $12.6 \%$ ) had communication problems, namely, lack of communication (Graph 1). 


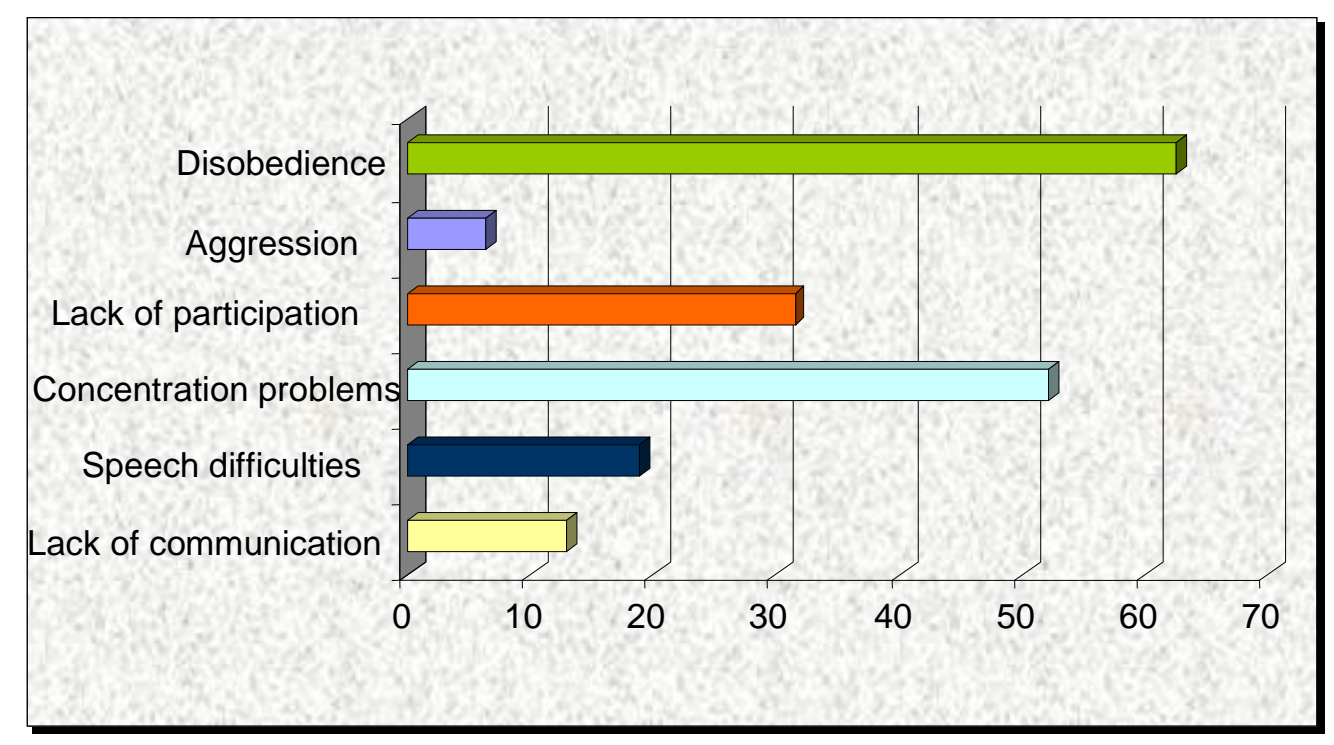

\section{Graph 1. Histogram rates of emotional problems and behavioral problems of children from single- parent families}

Moreover, in Table 2, the results of cross-tabulation between the emotional-behavioral problems and the degree of influence of single parenthood on children's adaptation to kindergarten are presented. Regarding the results of the analysis of the nursery school teachers' views, statistically significant differences were revealed (Fisher's Exact Test $=.039, p<.05$ ), according to which children were experiencing emotional problems, while at the same time it seems that single parenthood influenced the adjustment of children in kindergarten in a negative way, showing problems more frequently, as the kindergarten teachers assessed.

Table 2. Cross-tabulation of emotional problems-behavioral problems and the extent to which single parenthood has affected the adjustment: Number, frequency and statistical significance

\begin{tabular}{|c|c|c|c|c|}
\hline \multirow{2}{*}{\multicolumn{2}{|c|}{$\begin{array}{l}\text { Has single parenthood affected the child's } \\
\text { adjustment? }\end{array}$}} & \multicolumn{3}{|c|}{$\begin{array}{c}\text { Emotional problems - } \\
\text { Behavioral problems }\end{array}$} \\
\hline & & \multirow{2}{*}{$\begin{array}{c}\text { YES } \\
7 \\
87,5 \% \\
43,8 \%\end{array}$} & \multirow{2}{*}{$\begin{array}{c}\mathrm{NO} \\
1 \\
12,5 \% \\
7,1 \%\end{array}$} & \multirow{2}{*}{$\begin{array}{c}\text { Total } \\
8 \\
100,0 \% \\
26,7 \%\end{array}$} \\
\hline YES & $\begin{array}{l}\text { Number } \\
\% \text { Child's Adjustment } \\
\% \text { Problems }\end{array}$ & & & \\
\hline NO & $\begin{array}{l}\text { Number } \\
\% \text { Child's Adjustment } \\
\% \text { Problems }\end{array}$ & $\begin{array}{c}9 \\
40,9 \% \\
56,3 \%\end{array}$ & $\begin{array}{c}13 \\
59,1 \% \\
92,9 \%\end{array}$ & $\begin{array}{c}22 \\
100,0 \% \\
73,3 \%\end{array}$ \\
\hline Total & $\begin{array}{l}\text { Number } \\
\% \text { Child's Adjustment } \\
\% \text { Problems }\end{array}$ & $\begin{array}{c}16 \\
53,3 \% \\
100,0 \%\end{array}$ & $\begin{array}{c}14 \\
46,7 \% \\
100,0 \%\end{array}$ & $\begin{array}{c}30 \\
100,0 \% \\
100,0 \%\end{array}$ \\
\hline
\end{tabular}


Fisher's Exact Test $=.039(p<.05)$

Analysis and interpretation of results from the test 'family drawing' of L. Corman

According to the analysis of the family drawings of the children after separation/divorce of their parents and the children living with both parents, important issues were brought up.

The results of cross-tabulation supported the existence of statistically significant differences (Fisher's Exact Test $=.048, p<.05$ ) between children from single-parent and nuclear families, as far as the sex is concerned. In particular, in the drawings of the children from nuclear families, more figures of the same were depicted as opposed to those of children from divorced families. On the contrary, the cross-tabulation results did not support statistically significant differences (Pearson Chi-square $\chi^{2}=1.746$, $d f 1, n s$ ) between single-parent and nuclear families as to the children's identification. Although there were no statistically significant differences, it seems that single-parent family children identify themselves with other persons at a greater extent, whereas nuclear family children identify with themselves at a higher rate.

The checking of results has proved the existence of statistically significant differences among children from nuclear and single-parent families, regarding the features of the children's drawings: (a) regarding the form of the family shown in the children's drawings (Pearson Chi-square $\chi^{2}=27.708$, $d f 1, p<.001$ ), children from nuclear families drew their actual family at a higher percentage, while, in the case of children from single-parent families drawings, they primarily drew the imaginary family (Table 3), (b) regarding the extent of additions and omissions (Pearson Chi-square $\chi^{2}=13.611, d f 1, p^{<.001}$ ), in the drawings of the children from nuclear families, more omissions were found $(25,83.3 \%)$, which mainly concern the omissions of their siblings (Table 4). On the other hand, in the drawings of children from single-parent families, the additions were significantly more than the omissions $(19,63.3 \%)$, in which the person added was mostly that of the father, (c) regarding the number of colours (plain or multi-coloured) (Pearson Chi-square $\chi^{2}=7.500, d f 1, p<.01$ ), in the case of children from nuclear families, their drawings were more colourful and mainly with warm and bright colours, whereas in the case of children from single-parent families, their drawings were plain at a greater rate and mostly cool colours were used. Finally, the results of cross-tabulation 
between the drawing type (sensory - rational) and the form of family did not confirm the existence of statistically significant differences (Pearson Chi-square $\chi^{2}=.069, d f 1, n s$ ) among children of nuclear and single-parent families.

Table 3. Cross-tabulation between the family form and the real-imaginary family: Number, percentage frequency and control of statistical significance

\begin{tabular}{|c|c|c|c|c|c|c|}
\hline \multirow[b]{3}{*}{ Family } & \multicolumn{6}{|c|}{ Form of family } \\
\hline & \multicolumn{2}{|c|}{ Single-parent } & \multicolumn{2}{|c|}{ Nuclear } & \multicolumn{2}{|c|}{ Total } \\
\hline & $f$ & $\% f$ & $f$ & $\% f$ & $f$ & $\% f$ \\
\hline Real & 1 & $3,3 \%$ & 20 & $69,0 \%$ & 21 & $35,6 \%$ \\
\hline Imaginary & 29 & $96,7 \%$ & 9 & $31,0 \%$ & 38 & $64,4 \%$ \\
\hline
\end{tabular}

Table 4. Cross-tabulation between the family form and the additions-omissions in children's drawings: Number, percentage frequency and control of statistical significance

\begin{tabular}{|c|c|c|c|c|c|c|}
\hline \multirow[b]{3}{*}{ Additions-Omissions } & \multicolumn{6}{|c|}{ Form of family } \\
\hline & \multicolumn{2}{|c|}{ Single-parent } & \multicolumn{2}{|c|}{ Nuclear } & \multicolumn{2}{|c|}{ Total } \\
\hline & $f$ & $\% f$ & $f$ & $\% f$ & $f$ & $\% f$ \\
\hline Additions & 19 & $63,3 \%$ & 5 & $16,7 \%$ & 24 & $40,0 \%$ \\
\hline Omissions & 11 & $36,7 \%$ & 25 & $83,3 \%$ & 36 & $60,0 \%$ \\
\hline
\end{tabular}

Pearson Chi-square $\chi^{2}=13.611, d f 1, p<.001$

\section{Discussion and conclusions}

The close examination of not only the characteristics but also of the differences among students from nuclear and single-parent families after separation/divorce in our sample showed significant differences. In addition, it seems that approximately half of the children did not have a satisfactory relationship and contact with the absent parent, whereas the percentage of parents who did not have a satisfactory level of communication with each other was significantly high. More specifically, it appears that the two variables are closely related, revealing, thus, the fact that when parents did not have a proper communication with each other, the absence of a satisfactory relationship between the child and the absent parent was more than apparent. Such a fact reveals the need for a good relationship between the parents, 
as, in turn, it contributes to the efficient relationship between the child and the absent parent. According to various research findings, a high percentage of children have little contact and communication with the non-custodial parent (Amato, 1986 Furstenberg \& Nord, 1985), a situation which has been associated with the hostility and the ongoing conflicts of parents, concerning financial issues and their children's education (Fine, Moreland \& Schwebel, 1983).

As far as the school performance of the children of divorced parents is concerned, according to the findings, approximately half of them had a satisfactory school performance. However, their school performance seems to be influenced by factors related to single parenthood. More specifically, it was revealed that the children who had a good relationship with the absent parent had a better school performance, as opposed to those who did not have a good relationship with the absent parent, proving to some extent the importance of children's effective and functional relationship with both their parents. These findings are consistent with the results of other studies which bring us to the conclusion that the quality of interpersonal relationships acts as a safety net for the risk of failing at school, while the lack of communication with the absent parent -the father in particular- and his/her absence from his/her child's life have a negative impact on crucial developmental areas such as the child's psychological and emotional development, cognitive ability and academic success (Diaz, 2003; Hodges, Landis, Day \& Odelberg, 1991; Pliogkou, 2008).

An important part of the research objectives and goals of this study were the differences among children from nuclear and single-parent families, in some elements of which there were clear differentiations among them. Of course, the level of young children's sociability is not differentiated in relation to the form of family, according to their kindergarten teachers. Finally, regarding the children's school performance, no differences were found among children from different family forms. In the present research, the results are compatible with the findings of studies and research meta-analyses (Amato, 2000) on the effects of single parenthood on children's adaptation and well-being, which come to the conclusion that the impact of single parenthood is relatively low (Chapple, 2009; Francesconi, Jenkins \& Siedler, 2005).

A critical issue that seems to be associated with various characteristics of children from single-parent families appears to be the emotional and behavioral problems that may be developed. As far as the children of separated/divorced parents in our sample are concerned, a 
great number of them were characterized as quite energetic, while a significant number of them had concentration problems, did not participate in class and the educational process in general. Similar findings were shown in corresponding research in school age children (Babalis, 2005; Hatzichristou, 1999). Moreover, as a result of single parenthood, some children from single-parent families who participated in our research had speech difficulties and aggressiveness. Following are some of the remarks that are in compatibility with the statements of kindergarten teachers, according to which the single-parent family child: 'is lost in his world', 'withdrawn, as if he/she is not in class', 'immature, impaired', 'naughty, does not follow rules', 'energetic, disobedient', 'hits, teases other children with no reason at all'. These estimates are consistent with the findings of other studies that showed that the expected reactions of preschool age children, such as intense sadness and anger, are transferred to the wider environment and school and are manifested as immaturity, problems of attention/concentration and aggressiveness (Hetherington, Cox \& Cox, 1985; Pulkki-Rabach, Pullmann, Hintsanen, Alatupa, Ravaja, Lehtimaki, et al., 2010; Wallerstein \& Kelly, 1980).

At this point, it is worth mentioning previous studies which suggest that children of single-parent families and to a greater extent, children of divorced parents, face problems in various sectors of their psychosocial and school adjustment, as well as behavioral problems compared to children of nuclear families (Allison \& Furstenberg, 1989; Amato \& Keith, 1991; Hodges, Buchsbaym \& Tierney, 1983; Wallerstein, 1984).

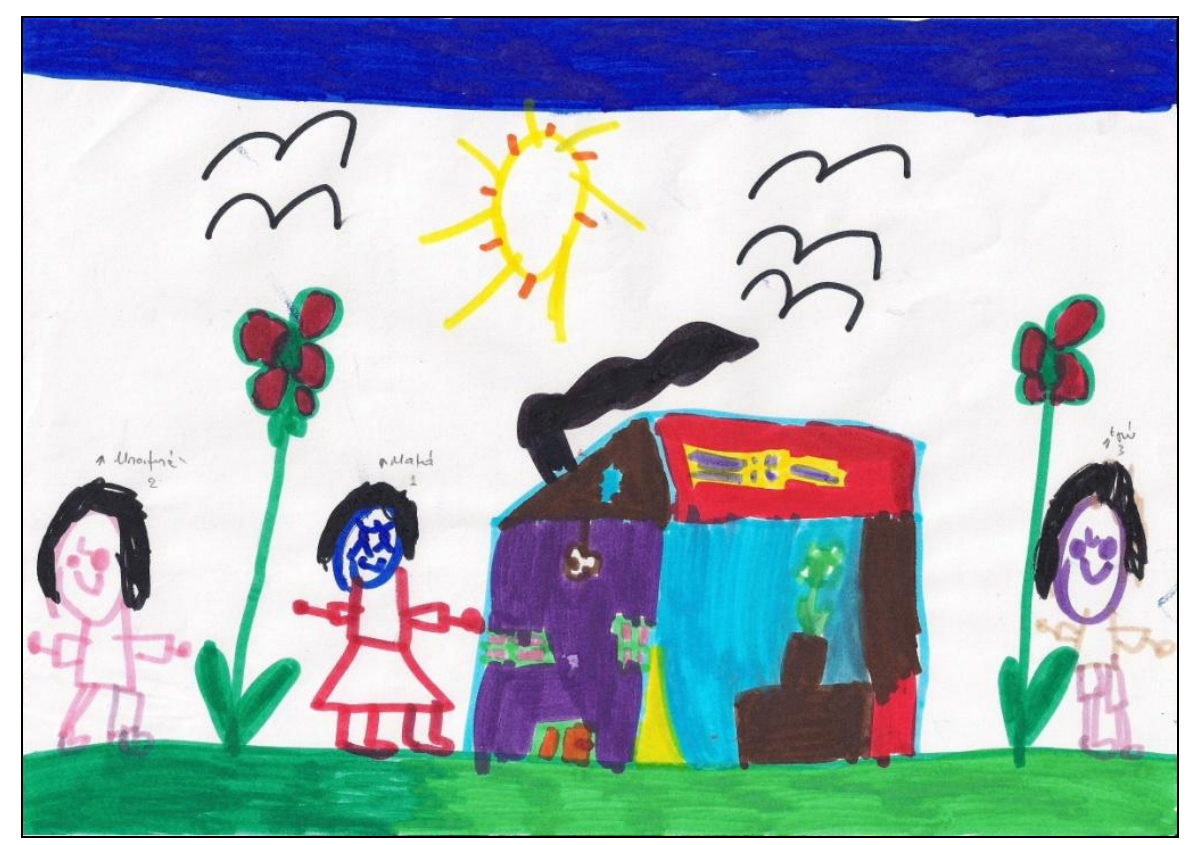




\section{Drawing N1. Giorgos, 5.5 years old, from a nuclear family}

The results of the analysis of children's drawings revealed significant differences among various features of children's drawing of both groups. To be more specific, in the cases of children from nuclear families the real family was portrayed at a higher percentage, while in the case of children from single-parent families after separation/divorce, the imaginary family was depicted at a higher rate, indicating that single parenthood significantly affects the children's drawings. Thus, the child of a single-parent family in our sample creates a family of his own invention in his drawing, without being obliged to face reality objectively and by making the changes he/she wants, creates a supportive environment that he/she needs and wishes for. An important feature, which was recorded and studied in the context of the analysis of children's drawings of the research at hand were the additions and omissions, revealing particularly important facts among children of divorced families and nuclear families. In particular, in the drawings of children from nuclear families, more omissions were found, mainly regarding the omission of their siblings, due to sibling rivalry (See drawing N1: ' $I$ drew mom, dad and me. The other siblings didn't fit. The least good? Michalis, the little one, who is always torturing me and Panayiotis', and drawing N2: 'the least good is my elder sister because she gets mad at me and the least happy is this little sister, as she cries because of something her sister did to her').

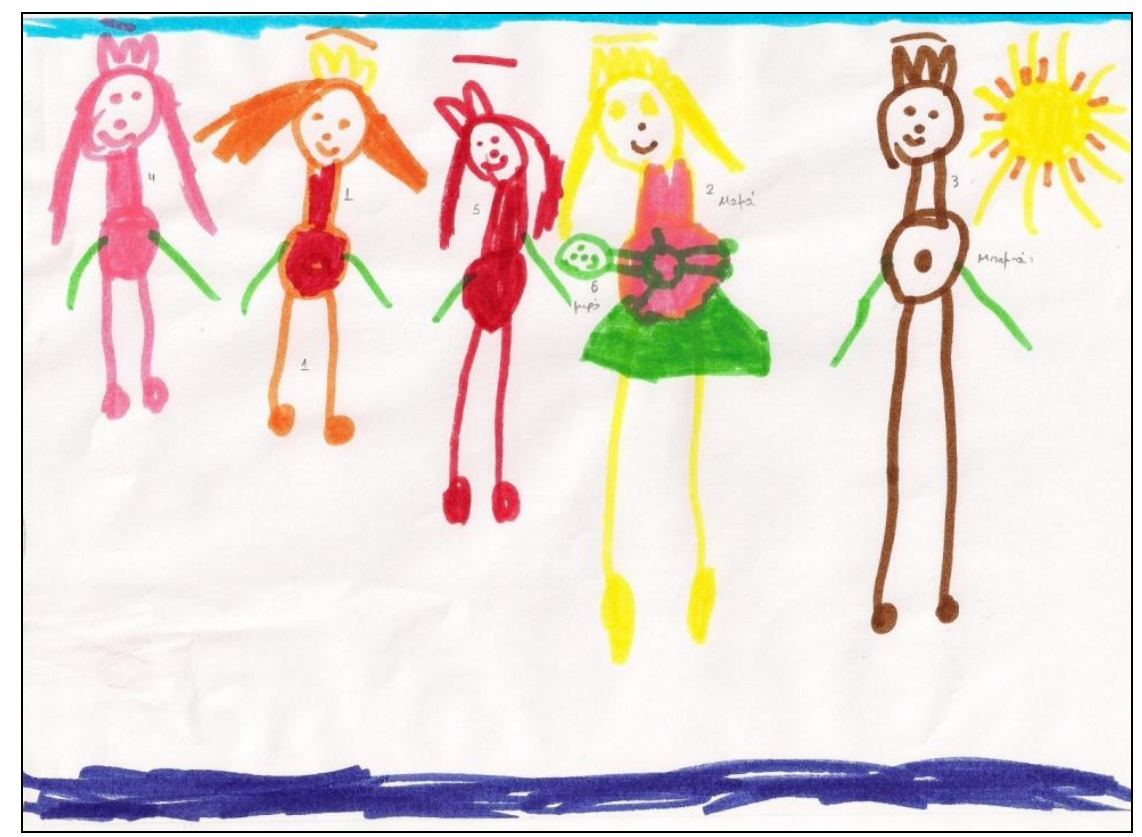

Drawing N2. Maria, 5.5 years old, from a nuclear family 
On the other hand, in the drawings of children of separated/divorced parents, additions were significantly more than omissions, in which the person added more was that of the absent parent-in their vast majority, that of the father-but without being attributed any value (as an overestimated person), as well as other persons of the wider family, such as cousins, uncles, grandparents, friends etc. (See drawing M1: 'This is my mom, this is my dad and my grandfather and my grandmother. The best in this family is my mom and my dad, because they raised me and love me more' and drawing M2: Although Irene's parents are divorced and she lives with her mother and her elder sister, she adds her father and another sister, expressing thus her personal view of family life and her desire for a wider family.

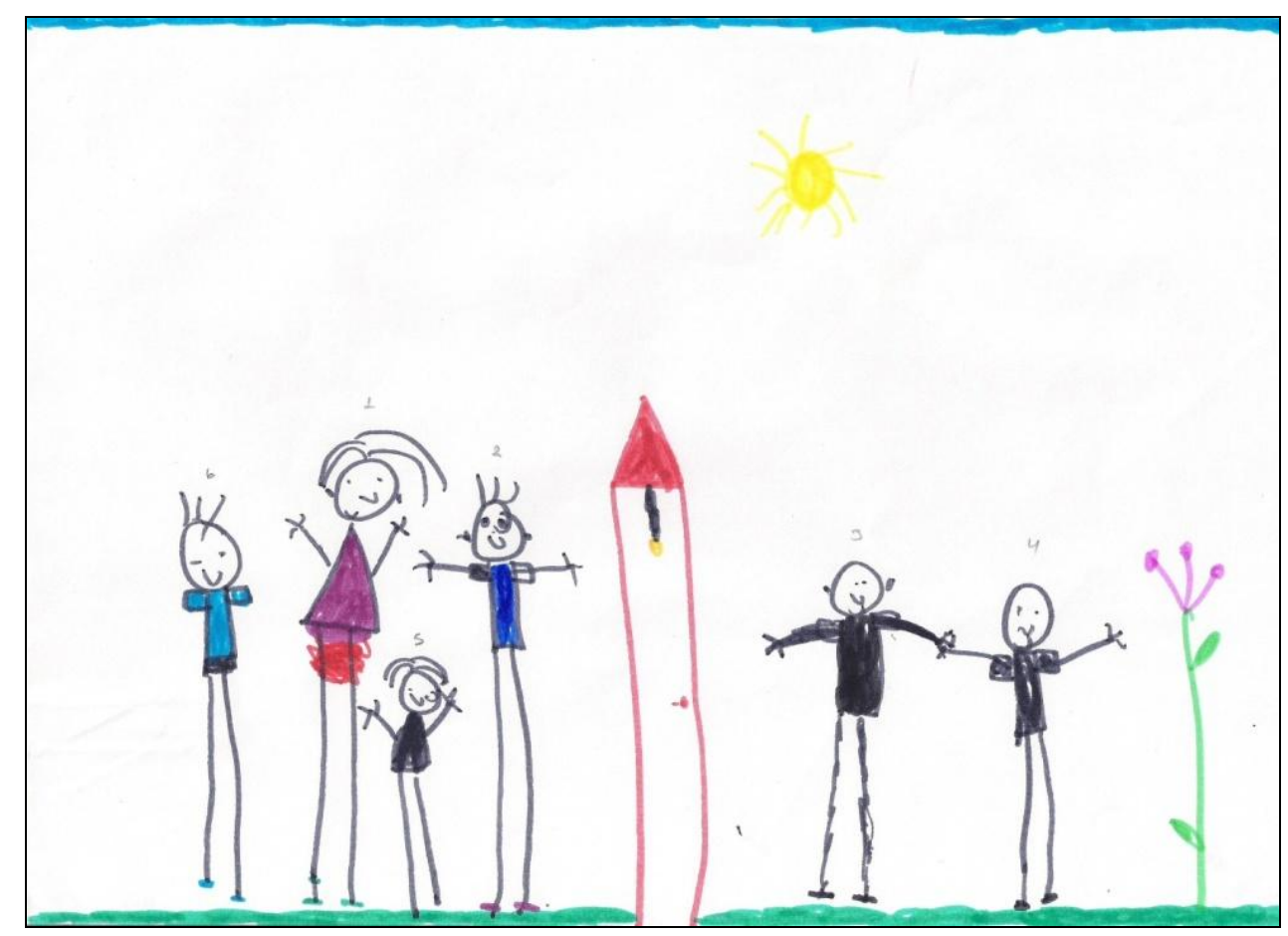

Drawing M1. Anthoula, 5 years old and 9 months, from a single-parent family 


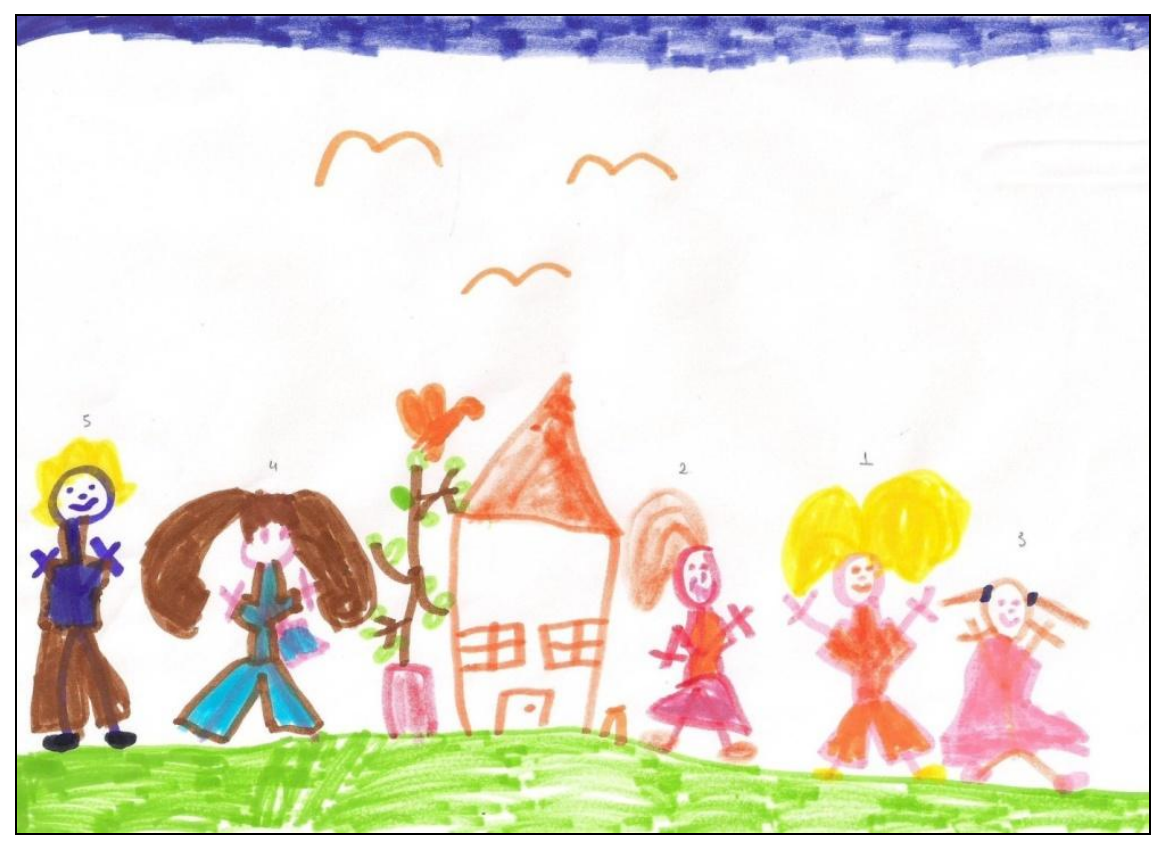

Drawing M2. Irene, 6 years old, from a single-parent family

According to Xanthakou (2007), children of single-parent families usually make additions (persons, folktale features, friends), so that they are able to manifest feelings they can not express verbally. The additions are representations that come to fill a gap, an emotional deprivation and play the role of the substitute which projects the child's intensions that he/she does not want to express.

Furthermore, in the drawings of our research, children of nuclear families depicted more persons of the same sex, as compared to those of divorced families. Finally, although no statistically significant differences were revealed, it appears that children of single-parent families identify themselves with other persons to a greater extent, whereas children of nuclear families identify with themselves at a higher rate.

The aforementioned findings are consistent with those reached by other researchers (Babalis, 2005; Xanthakou, 2007). The results of the present study confirm the value of children's drawing and especially of the family test as a diagnostic and evaluative tool of the power of the interfamilial relations and representations that the child has shaped about his family. At this point, the limitations of this study should be mentioned, as our sample was small and our intention was the comparative study of kindergarten students of single parent families after separation/divorce and children of nuclear families, regarding the basic features that define their adjustment in their family and school context. Our research was based on the assessments of teachers and children, while neither the parents' opinions on their children's 
adaptation were asked nor the communication between parents and school and their involvement in the educational process were taken into account. Furthermore, this study examined some characteristics of single parenthood and not the entire range of its dimensions. These could comprise the subject of a further study.

Nevertheless, some suggestions for the pedagogical use of the research findings can be made. The contemporary kindergarten, which primarily aims at children's cognitive, social and emotional development, can support these children, who, at such tender age, face difficult situations in life, in the following ways:

- Through the teacher's advisory role. It is of pivotal importance when the kindergarten teacher is in a position to recognize children's feelings, to accept and encourage their expression.

- Through useful tools, such as the use of puppets, drawing, fictional role play, the use of books and stories in the classroom (Carlile, 1991; Geldard \& Geldard, 2004).

- Through psychological support and counseling intervention programs for children of single-parent families (Hatzichristou, 1999).

- By informing and sensitizing school staff through training programs.

- Through the constant communication and collaboration with parents and their involvement in the educational process (voluntary help, creative activities with children, parental involvement in organizing events and educational activities, participation in collaborative activities with students and teachers)

- Through the promotion of an educational framework that is orientated to the social end emotional needs of all students and finally, through cooperation between school and authorities in the wider community.

A prerequisite for all the aforementioned is that both school and educational system aim at properly developing child's personality, promoting acceptance of diversity, respect and acceptance of different family forms, such as single-parent families (Zins, Weissberg, Wang, $\&$ Walberg, 2004).

In conclusion, constant work and effort are required to improve the work of preschool teachers, the upgrading of preschool educational programs and the provision of help to as many children as possible, regardless of conditions and circumstances. Kindergarten and pri- 
mary school could offer 'abilities rather than disabilities' to children of all social classes and family background, as we should not forget that children's adaptation and success in school are closely related to their social and emotional wellbeing (Epstein et al., 2002).

\section{References}

Allison, P. D., \& Furstenberg, F. F. (1989). How marital dissolution affects children: Variations by age and sex. Developmental Psychology, 25(4), 540-549.

Amato, P. R. (1986). Marital confict, the parent-child relationship and child self-esteem. Family Relations, 35, 403-410.

Amato, P. R. (2000). Children of divorce in the 1990s: An update of the Amato and Keith (1991) meta-analysis. Journal of Family Psychology, 15, 355-370.

Amato, P. R., \& Keith, B. (1991). Parental divorce and the well-being of children: A metaanalysis. Psychological Bulletin, 110(1), 26-46.

Argesti, A. (1990). Categorical data analysis. John Willey and Sons, New York.

Babalis, Th. (2005). Children from Single-parent Families: Helping school adjustment. Athens: Atrapos. (in Greek)

Bellas, T. (2000). The drawing of the child. Athens: Hellinika Grammata. (in Greek)

Bronfenbrenner, U. (1979). The ecology of human development. Cambridge, MA: Harvard University Press.

Bronfenbrenner, U. (2005). Making human beings human: Bioecological perspectives on human development. London: Sage Publications.

Cagliari, P., \& Giudici, C. (2002). School as a place of group learning for parents. In C. Guidici \& C. Rinaldi (Eds.), Making learning visible. Children as individual and group learners, Project Zero, Reggio Children, 136-147.

Carlile, C. (1991). Youngsters of Divorce: How teachers can help ease the pain. Childhood Education, 67, 232-334.

Chapple, S. (2009). Child Well-being and Family Structure across the OECD: An analysis. Draft Working Paper, Paris: OECD Publishing, forthcoming.

Cherlin, A., Furstenberg, F., Chase-Landsdale, P., Kierman, K., Robins, P., Morrison, D., \& Teitler, J. (1991). Longitudinal studies of the effects of divorce on children in Great Britain and the United States. Science, 252, 1386-1389.

Clay, M. (2001). Change over time in children's literacy development. Auckland, NZ: Heinemann. 
Commission of the European Communities, COM 89. 363 final. Brussels, 8 August 1989. Communication from the Commission on the family policies.

Corman, L. (1990). Le test de dessin de famille (6th ed.). Paris : Presse Universitaires de France.

Diaz, A. (2003). Personal, family, and academic factors affecting low achievement in secondary school. Electronic Journal of Research in Educational Psychology, 1, 43-66.

Dodge, D. T., \& Colker, L. J. (1998). The Creative Curriculum for early childhood. Washington, DC: Teaching Strategies Inc.

Epstein, J. L. (1995). School - Family - Community Partnerships: Caring for the children we share. Phi Delta Kappan, 76(9), 701-712.

Epstein, J. L., Sanders, M. G., Simon, B. S., Clark Salinas, K., Rodriguez Jansorn, N., \& Van Voorhis, F. L. (2002). School, Family, and Community Partnerships. Your Handbook for Action ( $2^{\text {nd }}$ ed.). Thousand Oaks, CA: Corwin Press, Inc.

Ermisch, J., Francesconi, M., \& Pevalin, D. J. (2004). Parental partnership and joblessness in childhood and their influence on young people's outcomes. Journal of Royal Statistical Society, 167(1), 69-101.

Fine, M. A., Moreland, J. R., \& Schwebel, A. J. (1983). Long-term effects of divorce on parent-child relationships. Developmental Psychology, 19(5), 703-713.

Francesconi, M. S., Jenkins \& Siedler, T. (2005). The impact of family structure during childhood on later-life attainment. Anglo-German Foundation for the Study of Industrial Society, September.

Furstenberg, F. F., \& Nord, C. W (1985). Parenting apart: Patterns of child rearing after marital disruption. Journal of Marriage and the Family, 47, 893-904.

Gall, M.D., Borg, W.R., \& Gall, J.P. (1996). Educational research: An introduction. Longman, NY: Longman Publishers.

Geldard, K., \& Geldard, D. (2004). The Counseling Psychology in children (M. MalikiosiLoizos Eds.) (3rd ed.). Athens: Ellinika Grammata. (in Greek)

Hatzichristou, C. (1999). The separation of parents, divorce and children. Athens: Hellinika Grammata. (in Greek)

Hellenic Statistical Authority (2009). Demographic Data. Private households by type and size and type of nuclear family. Census of March 18, 2001. Available on http://www.statistics.gr/portal/page/portal/ESYE (in Greek) 
Herbert, M. (2008). Separation and divorce: Helping children to cope (6th ed.). (B. Papadioti-Athanasiou, Ed., G. Moraitis, Trans.). Athens: Ellinika Grammata. (in Greek)

Hetherington, E. M. (1989). Coping with family transitions: Winners, losers, and survivors. Child Development, 60, 1-14.

Hetherington, E. M., Bridges, M., \& Insabella, G. M. (1998). What matters? What does not? Five perspectives on the association between marital transitions and children's adjustment. American Psychologist, 53(2), 167-184.

Hetherington, E. M., Cox, M., \& Cox, R. (1985). Long-term effects of divorce and remarriage on the adjustment of children. Journal of the American Academy of Child Psychiatry, 24(5), 518-530.

Hodges, W. F., Buchsbaym, H. K., \& Tierney, C. W. (1983). Parent-child relationships and adjustment in preschool children in divorced and intact families. Journal of Divorce, 7, 43-48.

Hodges, W. F., Landis, T., Day, E., \& Odelberg, N. (1991). Infant and toddlers and post divorce parental access: An initial exploration. Journal of Divorce and Remarriage, 14, 239-252.

Kalter, N., \& Rembar, J. (1981). The significance of a child's age at the time of parental divorce. American Journal of Orthopsychiatry, 51, 85-100.

Kardasi, I. (2005). Single-parent families from divorce: effects on psychosocial development of adolescent. PhD thesis. Thessaloniki: School of Early Childhood Education, Aristotle University of Thessaloniki. (in Greek)

Kogkidou, D. (1995). Single-parent families: Fact-Perspectives-Social policy. Athens: Livanis. (in Greek)

Koutrouba, K., Antonopoulou, K., \& Babalis, Th. (2010). Parental involvement in secondary education schools: The views of parents in Greece. Educational Studies, 33, 14653200 .

Malchiodi, C. (2001).Undrestanding children's painting. (N. Anagnostopoulou, ed., \& C. Xenaki, L. Papadopoulou, Trans.). Athens: Hellinika Grammata. (in Greek)

McLanahan, S., \& Sandefur, G. (1994). Growing up with a single parent. Harvard University Press, Cambridge, MA.

Miller, W.R., Yahne, C.E., \& Rhodes, J.M. (1990). Adjustment. The psychology of change. Englewood Cliffs, N.J.: Prentice Hall.

OECD (2009). Child Well-being and Single Parenthood. In Doing Better for Children, chapter 5, 125-145. Paris: OECD Publishing. 
Pliogkou, B. (2008). The effect of single parenthood in the educational success of children. PhD thesis. Thessaloniki: Department of Primary Education, Aristotle University of Thessaloniki. (in Greek)

Pong, S. L., Dronkers, J., \& Hampden-Thompson, G. (2002). Family Policies and Academic Achievement by Young Children in Single-Parent Families: An International Comparison. The Population Research Institute, The Pennsylvania State University, with The Amsterdam School of the Social Sciences (University of Amsterdam) and the European University. Working Paper 02-03.

Pulkki-Rabach, L., Pullmann, H., Hintsanen, M., Alatupa, S., Ravaja, N., Lehtimaki, T., et al., (2010). Hyperactivity in childhood as a predictor of school performance in elementary school: Modifying effect of a serotonin receptor gene (5-HTR2A). Electronic Journal of Research in Educational Psychology, 8, 971-990.

Rathus, S.A., Nevid, J.S., \& Piggrem, G.W. (1986). Adjustment and growth. The challenges of life. New York: International Tomson Publishing.

Riga, A. B., \& Gkiziaki, E. (1994). Psychosocial and demographic characteristics of the Greek mother headed single parent family - Case studies. In B. Kotzamanis, \& L. Maratou (Ed.), The demographic trends in post-war Greece. Athens: A. A. Livanis. (in Greek)

Siegel, S., \& Castellan, N.J. (1988). Nonparametric statistics for the behavioral sciences $\left(2^{\text {nd }}\right.$ ed.). New York: McGraw-Hill.

Wallerstein, J. S., \& Kelly, J. B. (1980). Surviving the breakup: How children actually cope with divorce. New York: Basic Books.

Wallerstein, J.S. (2001). The unexpected legacy of divorce: 25 year landmark study. New York: Hyperion Press.

Wallerstein, J.S. (2003). What about the kids? Raising your children before, during and after divorce. New York: Hyperion Press.

Xanthakou, Y. (2007). Drawing an Imaginary Family. Athens: Atrapos. (in Greek)

Zins, J., Weissberg, R., Wang, M., \& Walberg, H. (2004). Building academic success on social and emotional learning. New York: Teachers College Press, Columbia University. 